\title{
Indonesian banking performance based on BUKU
}

\author{
Juliana Kadang \\ Faculty of Economic and Business, Universitas Tandulako \\ juliana_kadang@untad.ac.id \\ Surayya \\ Faculty of Economic and Business, Universitas Tandulako \\ surayyathamrin@untad.ac.id \\ Muh. Fasial \\ Faculty of Economic and Business, Universitas Tandulako
}

Received: October, 2020; Accepted: January, 2021; Published:

September, 2021

DOI: https://doi.org/10.24123/imb.v20i2

\begin{abstract}
The improvement in the performance of Indonesian banking when the global economy is being hit by uncertainty is one of the best achievements. Acquiring profitability is accompanied by an increase in efficiency in using available resources to gain profit. This study aims to measure and analyze the performance of Indonesian banking based on Profit Efficiency. Profit Efficiency of a bank is analysed based on BUKU (Bank Umum Kelompok Usaha). The profit Efficiency is measured using the Sthocastic Frontier Analysis (SFA) Frontier 4.1 with the translog model of Alternative Profit Efficiency. The input variables used are: labor costs, physical capital costs and interest costs. The output variable used is the amount of credit and the amount of other productive assets. The model equation used is the Bank Activity Approach. The total sample was 19 commercial banks listed on the Indonesia Stock Exchange (IDX) and had financial reports from the year of 2010 to 2019. The results of banking Profit Efficiency measurement based on BUKU conclude that BUKU 2 indicated that each bank's Profit Efficiency tends to be increasingly inefficient. BUKU 3 of profit efficiency of banks tends to be more efficient. BUKU 4 shows that banks in this group of Profit efficiency are increasingly efficient. This means that the greater the bank's core capital, the more efficient it is in generating profits.
\end{abstract}

Keywords: profit efficiency, Stochastic Frontier Analysis (SFA), core capital 


\begin{abstract}
Abstrak
Peningkatan kinerja Perbankan Indonesia disaat perekonomian dunia tidak menentu merupakan salah satu prestasi sangat baik. Perolehan profitabilitas sejatinya disertai dengan peningkatan efisiensi dalam menggunakan sumber daya yang dimiliki untuk memperoleh profit. Penelitian ini bertujuan untuk mengukur dan menganalisis kinerja perbankan Indonesia berdasarkan Profit Efficiency. Menganalisis Profit Efficiency bank berdasarkan BUKU (Bank Umum Kelompok Usaha). Pengukuran Profit Efficiency menggunakan Sthocastic Frontier Analysis (SFA) Frontier 4.1 dengan menggunakan translog model Alternative Profit Efficiency. Variabel input yang digunakan adalah: biaya tenaga kerja, biaya modal fisik dan biaya bunga. Variabel output yang digunakan adalah jumlah kredit dan jumlah aktiva produktif lainnya. Persamaan modelnya menggunakan Pendekatan Aktivitas Bank. Jumlah sampel 19 bank umum yang terdaftar di Bursa Efek Indonesia (BEI) dan memiliki laporan keuangan dari tahun 2010 - 2019. Hasil pengukuran Profit Efficiency Perbankan berdasarkan BUKU menyimpulkan bahwa BUKU 2 memperlihatkan bahwa Profit Efficiency masing-masing bank cenderung semakin tidak efisien. BUKU 3 Profit Efficiency bank cenderung semakin efisien. BUKU 4, bank dalam kelompok ini Profit Efficiency semakin efisien. Bermakna bahwa semakin besar modal inti yang dimiliki oleh bank semakin efisien dalam menghasilkan profit.
\end{abstract}

Kata Kunci: Profit Efficiency, Sthocastic Frontier Analysis (SFA), modal inti

\title{
INTRODUCTION
}

The development of banking performance until the end of 2019 is an indicator of improving Indonesian banking conditions. The increase in performance was described in several commercial banks such as PT Bank Rakyat Indonesia (PT. BRI) which achieved net profit of Rp. 34.4 trillion at the end of 2019. The amount of credit disbursed by PT. BRI throughout 2019 increased by $8.44 \%$ compared to 2018 , above the average industrial credit growth of $6.08 \%$. Bank Mandiri, its profit growth throughout 2019 increased by $9.9 \%$ compared to 2018 . Consolidated credit growth was $10.7 \%$ (YoY). Credit growth of 10.7 (YoY) until reach Rp.907.5 trillion in 2019. Net interest income of Rp.59.4 trillion, an increase of $8.8 \%$ (YoY) compared to 2018. PT. BNI, Tbk made a profit of Rp.15.38 trillion throughout 2019. This achievement increased by $2.5 \%$ compared to the previous year of Rp. 15.02 Trillion. The net profit growth is $10.3 \%$ (YoY) from the position of Rp.13.62 Trillion at the end of 2017. This profit achievement was supported by credit distribution which increased by $8.6 \%$ YoY, so that the effect of Net Interest Income (NII) increased by $3.3 \%$ compared to 2018 (KSK 33 dan 34 2019).

Escalating bank profits and performance is one of the efforts to 
manage Third-party Funds in ensuring the welfare of company owners, especially in helping to increase economic growth. Measuring the level of efficiency in managing Third-party Funds and other funding sources such as core capital used in obtaining profits is an important indicator. Efficiency is a measure that shows how economic resources are used in the production process to produce output. Likewise, banks manage Thirdparty Funds and capital owned by each bank. The more efficient banking sector has contributed to relatively maintained profitability amid slowing credit growth, as reflected in the return on assets (ROA), which was at its highest level in the last 3 years. Profitability is still maintained at a level above $2 \%$, as reflected in the ROA of banks of $2.47 \%$ in the first semester of 2019 , only slightly decreasing from $2.5 \%$ in the second semester of 2018 (KSK 33 2019).

Like a company, a bank aims to achieve the maximum possible economic profit, so that the company creates the maximum possible margin between total revenue and total economic cost. The effect of profit maximization is assumed to drive the basic objectives of decisions made by companies (Snyder, 2010). The measurement of Profit Efficiency has taken into account inefficiencies both in terms of input and output. The advantages of using profit efficiency include that it allows the measurement of inefficiency on the output side to be the same as the measurement of inefficiency based on the input side and reduces the problems associated with errors in determining and measuring input and output variables (Berger et al., 1993).

Measurement of bank efficiency often uses the OEOI (Operating Expenses to Operating Income) ratio. According to Qurniawati (2013) the OEOI ratio is a ratio that is often used in measuring efficiency because of its ease of measurement, still this ratio also has a weakness, which is not able to describe the actual condition of the bank and the results of the assessment are not easy to interpret. Efficiency measurement should include input and output in obtaining profit (Firdaus \& Hosen, 2014).

This study measures the Profit Efficiency using the parametric approach of Stochastic Frontier Analysis (SFA) and analyses the Profit Efficiency based on BUKU. The difference between this research and the research that has been conducted by Nisa (2018), Sari \& Widaninggar (2018) and Qurniawati (2013) is the approach to measuring Profit Efficiency. Previous research used a non-parametric approach, Data Envelopment Analysis (DEA). DEA uses a nonstochastic approach and tends to combine interference and inefficiency.

\section{Profit Efficiency}

The company has a goal of maximizing profit, so that the company tries to make the most considerable possible difference between total revenue and total economic costs. It is assumed that profit maximization is an objective driver of companies' decisions (Walter \& Snyder, 2010). Likewise, banks, which function as intermediaries, collect funds from the 
public and distribute credit to the public. Banks are also one of the transmission routes for the implementation of Bank Indonesia monetary policy. The bank, in running its business, also has a goal of maximizing the profits it makes. The bank system's ability to carry out its functions efficiently is closely related to sound and efficient bank management (Darmawi, 2012).

Efficiency is one part of the overall performance of a company. Company performance appraisal is based on effectiveness and efficiency. The effectiveness measure the company's performance based on the level of achievement of programs and policies achieved based on the results of achievement, quality and suitability. Efficiency is the company's performance by measuring the management of the company's resources. Efficiency is a description of financial performance that shows the company's ability to manage its resources and this is very important for the stakeholders (Porcelli, 2009) and (Aymen, 2013).

A company is said to be efficient if it can minimize production costs to produce output at a certain level with a level of technology used and the prevailing market price level (Porcelli, 2009). The results of the Profit Efficiency measurement are stated as real profits compared to the maximum profit that should be achieved by a bank. The efficiency value is between 0 and 1 , so that if it is less than 1 (one) means that it is more inefficient (Coelli, 2005:244).

The measurement of Profit Efficiency is a derivation of the profit function which has advantages (Berger et all,. 1993) which are: first, the profit function allows the measurement of inefficiency on the output side to be the same as the measurement of inefficiency based on the input side. Second, reducing the problems associated with the error in determining input and output variables in measuring Profit Efficiency. Third, indicates the sources of inefficiency, especially the impact of bank merger and branching regulations.

This economic profit function below describes the company in maximizing profit based on the price (Walters \& Snyder, 2010:369)

$\pi=P q-C=P f(k, l)-v k-w l$

In this case the variables $k$ and $/$ are the input which is a function of the output $[(\mathrm{q}=\mathrm{f}(\mathrm{k}, \mathrm{l})]$. The variable $P$ is the output value. The variables $k$ and $I$ are the inputs used to maximize profit where $P$ is the price of the output, $v$ and $w$ are the costs of each input $k$ and $I$. It can be concluded that the profit function in maximizing profit is as follows:

$\pi(P, v, w) \max _{k, l} \pi(k, l)=\max _{k, l}[P f(k, l)-v k-w l]$

This study uses a parametric approach to measure Profit Efficiency. The measurement uses the Stochastic Frontier Approach (SFA). The parametric approach conducts the measurements by using stochastic econometrics and seeks to eliminate distractions from the effects of inefficiency. Previous research conducted by Tahir and Haron (2008) and 
Sharma et al (2012) measured efficiency using the Stochastic Frontier Approach (SFA).

2. Bank Umum Kelompok Usaha (BUKU)

Bank Indonesia Regulation No. 14/26 / PBI / 2012 regarding business activities and office networks based on bank core capital divides the bank into 4 business groups, as follows:

1. BUKU 1 is able to carry out activities to raise and distribute funds which are the essential products or activities in Rupiah, trade financing activities, activities with limited scope for agency and cooperation, payment system activities and electronic banking with limited coverage, temporary equity participation activities in the context of credit rescue, and other services, in Rupiah. BUKU 1 can only perform limited foreign exchange activities as a foreign exchange trader.

2. BUKU 2 is able to carry out product activities or activities in Rupiah and foreign currencies with a wider scope than BUKU 1. BUKU 2 can carry out limited treasury activities including spot and derivative plain vanilla as well as invest of $15 \%$ in domestic financial institutions.

3. BUKU 3 is able to conduct all business activities in Rupiah and foreign currencies and participate of $25 \%$ in financial institutions within and outside the country, limited to the Asian region.

4. BUKU 4 is able to conduct all business activities in Rupiah and foreign currencies and participate of $35 \%$ in domestic and foreign financial institutions with a wider coverage area than BUKU 3 (international worldwide).

Core capital based on Bank Indonesia Regulation (PBI) Number: 14/18 / PBI / 2012 is the core capital owned by each bank headquartered in Indonesia, consisting of: core capital (tier 1), supplementary capital (tier 2) and additional supplementary capital (tier 3). Capital for branch offices located abroad consists of: business funds, retained earnings, profit for the year of $50 \%$ and general capital reserves.

Capital and financial performance are the two important variables in the banking sector. These two variables illustrate the bank's ability to achieve sustainable benefits from raised capital and overcome systemic risk. The greater the core capital owned by a bank, the wider the scope of its financial services and network activities will be. The increase in core capital is expected to improve the performance of banks in managing their inputs so that the level of efficiency in generating profits will increase. As research conducted by Nisa et all. (2018) measures the level of efficiency based on Data Envelopment Analysis (DEA). The results of the research indicate that banks that are included in the BUKU 4 group are more efficient than banks in other BUKU categories. 


\section{RESEARCH METHOD}

The sample of this research is the banks listed on the Indonesia Stock Exchange (IDX). The sampling technique used was purposive sampling. This is the sampling method based on the criteria required in accordance with the research objectives. The sampling requirements are: first, being active and listed on the Indonesia Stock Exchange (IDX). Second, publishing complete financial reports from the year 2010 to 2019. Third, banks did not experience losses from 2010 to 2019. Based on these conditions, the number of bank samples that met the requirements was 19 banks.

The concept of measuring Profit Efficiency uses Alternative Profit Efficiency with the bank intermediation approach. This concept's choice is based on previous research conducted by (Berger \& Mester, 1997) that the Profit Efficiency approach is better than the cost efficiency approach. Profit Efficiency has taken into account inefficiencies both from the input and output sides, while cost-efficiency is only on the input side. Cost efficiency is based on the minimum cost at a specific output level, while the output is not necessarily at the optimal level of output.

The bank will maximize profits by choosing the output price $(p)$ and the amount of input $(x)$, for the number of output $(y)$ and the input price $(r)$. The alternative indirect profit function is a solution to the optimization problem with the following function below:

Max $\pi_{p . x \prime}=P^{\prime} Q=(p, w)(y-x)^{\prime}$, where $s, t, g(p, y, w, z)=0$ and $h(y, x)=0$.

The Profit Efficiency measurement model uses the development of the Activity Bank Approach model using the translog model of Alternative Profit Efficiency. The Activity Bank Approach measures all bank activities that generate profits (Kadang et all., 2018). The function is as follows:

$$
\begin{aligned}
\ln \left[(\pi)+\mid\left(\pi_{\min }\right)\right. & +1 \mid] \\
& =\beta_{0}+\beta_{\mathrm{w} 1} \ln \left(w_{1 i}\right)+\beta_{\mathrm{w} 2} \ln \left(w_{2 i}\right)+\beta_{\mathrm{w} 3} \ln \left(w_{3 i}\right)+\beta_{\mathrm{k}} \ln \left(y_{i}\right)+\beta_{\mathrm{A}} \ln \left(A_{i}\right)+\frac{1}{2} \beta_{\mathrm{w} 11} \ln \left(w_{1 i}\right)^{2} \\
& +\frac{1}{2} \beta_{\mathrm{w} 22} \ln \left(w_{2 i}\right)^{2}+\frac{1}{2} \beta_{\mathrm{w} 33} \ln \left(w_{3 i}\right)^{2}+\beta_{\mathrm{w} 1 \mathrm{y}} \ln \left(w_{1 i}\right) \ln \left(y_{i}\right)+\beta_{\mathrm{w} 2 \mathrm{y}} \ln \left(w_{2 i}\right) \ln \left(y_{i}\right) \\
& +\beta_{\mathrm{w} 3 \mathrm{y}} \ln \left(w_{3 i}\right) \ln y_{i}+\beta_{\mathrm{w} 1 \mathrm{y}} \ln \left(w_{1 i}\right) \ln \left(A_{i}\right)+\beta_{\mathrm{w} 2 \mathrm{y}} \ln \left(w_{2 i}\right) \ln \left(A_{i}\right)+v_{a \pi}-u_{a \pi}
\end{aligned}
$$

In this case : total bank profit $n,=$ the input price of bank $i$ is the price of labor $\left(w_{1}\right)$, the price of physical capital $\left(w_{2}\right)$ and the price of interest costs, $=$ total credit at bank $i, A_{i}=$ total assets other productive that is not included in the bank intermediation function of bank $i$, = controllable (random) factor which describes the inefficiency factor so that it can reduce a bank's profit below the bank's best practice profit, = uncontrollable factor or noise term.

Determining the input-output used in the model is using the intermediation approach. The intermediation approach is considered more 
appropriate for evaluating all banks compared to the production approach and can evaluate the importance of the efficiency frontier to probability by minimizing the total cost (not just production costs) required to maximize profit.

The input variable used is salary expense, operating costs minus salary costs, interest costs. The output variable consists of the amount of credit and the number of other productive assets such as investment of funds in both Rupiah and foreign currency in the form of securities, placement of funds between banks. Table 1 summarizes the input variables used in this study.

Table 1. Variable Input

\begin{tabular}{ll}
\hline \multicolumn{1}{c}{ Variable } & \multicolumn{1}{c}{ Definition of Variable } \\
\hline Price of labor costs $\left(W_{1}\right)$ & Labor cost / Total Assets \\
Physical capital cost price $\left(W_{2}\right)$ & (Operating cost - Salary cost) / Total Assets \\
Interest cost price $\left(W_{3}\right)$ & Interest cost / Total fund of third parties \\
\hline
\end{tabular}

To classify banks based on BUKU according to Bank Indonesia Regulation No. 14/26/PBI/2012 regarding business activities and office networks based on bank core capital divides the bank into 4 (four) business groups as follows, BUKU 1, Banks with core capital less than IDR 1 Trillion; BUKU 2, Banks with core capital of IDR 1 trillion to less than IDR 5 trillion; BUKU 3, Banks with core capital of IDR 5 trillion to less than IDR 30 trillion; and BUKU 4, Banks with core capital above IDR 30 trillion.

\section{RESULT AND DISCUSSION}

Based on the results of data processed by using the Stochastic Frontier Approach (SFA) frontier 4.1, the overall average Profit Efficiency is 0.67 which means that the Profit Efficiency based on the research conducted in the year of 2010-2019 tends to be more efficient, because the Profit Efficiency value is close to 1. The performance of Indonesian banking during the year of research in 2010-2019 in managing the three main inputs, which are costs labour, physical capital costs and interest costs in generating profits are not optimal.

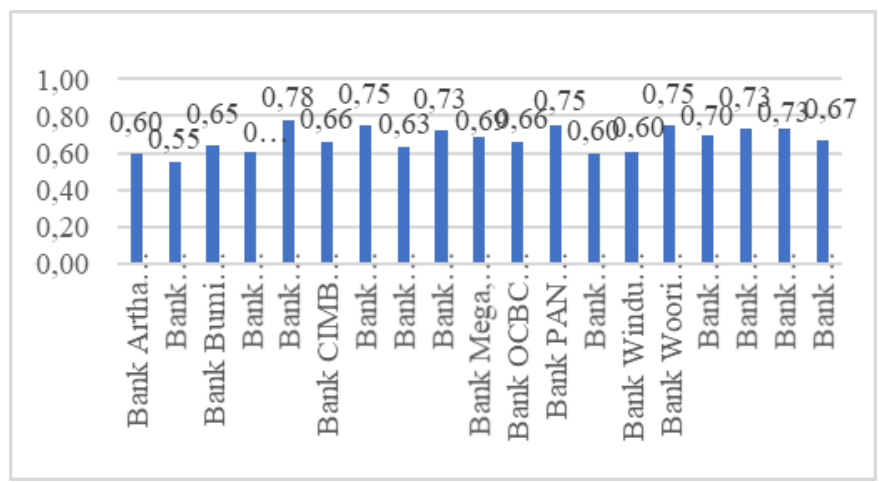

Figure 1. Profit Efficiency Bank 2010-2019

Data source: Processed 
Figure 1, describes the performance of 19 banks listed on the Indonesia Stock Exchange (IDX). BUKOPIN Bank has the smallest performance compared to other banks. Profit Efficiency of 0.55 , which means that the BUKOPIN Bank's ability to manage inputs (labor costs, physical capital costs and interest costs), credit management and productive assets compared to other banks is still low.

Central Asia Bank, Danamon Bank, Indonesia International Bank, PANIN Bank, Windu Kentjana Bank, Mandiri Bank, BNI and BRI have good Profit Efficiency. Central Asia Bank has the closest performance in obtaining profit compared to other banks.

Bank grouping based on BUKU is according to the core capital owned by each bank. Based on the results of the measurement of Profit Efficiency, grouping based on business activities is illustrated as follows:

Table 2. Average of Profit Efficiency Based on BUKU

\begin{tabular}{lllcc}
\hline \multicolumn{1}{c}{ Category of BUKU } & Number of Banks & Average & Min & Max \\
\hline BUKU 2 & 9 & 0,63 & 0,55 & 0,75 \\
BUKU 3 & 4 & 0,69 & 0,63 & 0,75 \\
BUKU 4 & 6 & 0,72 & 0,66 & 0,78 \\
\hline
\end{tabular}

Data source: Processed

The results of grouping the average profit efficiency in Table 2 indicate that banks based on the BUKU 2, BUKU 3 and BUKU 4 business groups tend to have an efficiency ratio of close to 1 (one). This means: first, that the bank's ability to manage the inputs (labour costs, physical capital costs and interest costs) based on its core capital is still not optimal. Second, the amount of core capital owned by each bank does not affect the bank's ability to generate profits.

Table 3 describes each bank's profit efficiency based on BUKU. It signifies that the profit efficiency of each bank tends to be inefficient. Only Woori Saudara Indonesia Bank 1906 Tbk has a higher efficiency value than those similar banks. Banks that are in the BUKU 3 Profit Efficiency group are getting more efficient and the banks that are including in the group of BUKU 4.

The business activities of BUKU 2 are narrower than those of BUKU 3 and 4 (PBI No.14/26/2012). That business activity is the treasury. Treasury activities include the management of bank liquidity, asset management, liabilities and as a profit-seeking unit. The types of business activities of BUKU 3 and BUKU 4 are the same. The difference lies only in the amount of core capital owned by banks in the BUKU 3 and BUKU 4 groups. Banks in the BUKU 3 group have core capital of at least IDR 5 trillion to less than IDR 30 trillion. Meanwhile, banks in the BUKU 4 category have core capital of more than 30 trillion. Based on the amount of core capital, banks in the BUKU 4 group can be categorized as banks with large asset sizes. The greater the resources owned by the bank will increase the bank's ability to maximize its operational activities, so that efficiency can be achieved (Sari \& Widaninggar, 2018). This suggests 
that the greater the amount of capital a bank has, the more efficient it is in generating profits.

Table 3. Profit Efficiency Bank Based On BUKU

\begin{tabular}{cll}
\hline BUKU & \multicolumn{1}{c}{ Name of Bank } & Profit Efficiency \\
\hline 2 & Bank Artha Graha International, Tbk. & 0,60 \\
& Bank Bukopin, Tbk, PT. & 0,55 \\
& Bank Bumi Artha, Tbk, PT & 0,65 \\
Bank Capital Indonesia, Tbk. & 0,61 \\
Bank Mega, Tbk, PT & 0,69 \\
Bank OCBC NISP, Tbk. & 0,66 \\
Bank Rakyat Indonesia Agroniaga, Tbk, PT & 0,60 \\
Bank Windu Kentjana International, Tbk. & 0,60 \\
Bank Woori Saudara Indonesia 1906, Tbk. & 0,75 \\
3 & 0,75 \\
Bank Danamon Indonesia, Tbk. & 0,63 \\
Bank International Indonesia, Tbk. & 0,73 \\
Bank Mayapada International, Tbk. & 0,67 \\
Bank Tabungan Negara (Persero), Tbk. & 0,78 \\
Bank Central Asia, Tbk. & 0,66 \\
Bank CIMB Niaga, Tbk. & 0,75 \\
Bank PAN Indonesia, Tbk. & 0,70 \\
Bank Mandiri (Persero), Tbk. & 0,73 \\
Bank Negara Indonesia (Persero), Tbk. & 0,73 \\
Bank Rakyat Indonesia (Persero), Tbk. &
\end{tabular}

Data source: Processed

The greater the capital owned by the bank, the greater the commitment of shareholders to the continuity of bank operations. Gambacorta \& Shin (2018) in their research state that there is a positive influence on the greater core capital owned by banks. This is related to the cheaper cost of funds if the amount of capital owned by the bank increases. The cost of funds that is cheaper than the capital owned by the bank will affect the net interest margin that the bank receives.

Cost of the fund is one of the bank inputs managed by the bank to generate profit. The largest source of funding for banks is the Third-party funds in the form of savings and deposits then channeled by banks in credit. Credit products generate interest income. Banks are expected to collect Third-party funds as much as possible with minimal interest costs so that the interest cost input variable can increase the value of Profit Efficiency.

\section{CONCLUSION}

This research concludes that the Profit Efficiency of a bank based on BUKU is determined by the amount of core capital and the ability of each bank to manage its core capital. Apart from acquiring maximum thirdparty funds, the banks must also maximize their efforts to increase their capital. Therefore, the cost of funds that has to be paid is cheaper. It will affect interest income to increase. Further research can analyze the 
influence of Profit Efficiency related to the capital structure of a bank. It is because the source of bank funding does not only come from capital but also from debt.

\section{REFERENCES}

Aymen, B. M. M. (2013). Impact of capital on financial performance of banks: The case of Tunisia. Banks and Bank Systems, 8(4): 47-54.

Berger, A. N., Hancock, D. and Humphrey, D. B. (1993). Bank efficiency derived from the profit function. Journal of Banking and Finance, 17(2-3) : 317347. doi: 10.1016/0378-4266(93)90035-C.

Berger, A. N. and Mester, L. J. (1997). Inside the black box: What explains differences in the efficiencies of financial institutions?. Journal of Banking and Finance, 21(7): 895-947. doi: 10.1016/S0378-4266(97)00010-1.

Coelli, T.J, Rao, D.S.P., O'Donnell, C.J., Battese, G. E. (2005) an Introduction To Efficiency and Productivity. Springer.

Darmawi, H. (2012). Manajemen Perbankan. Cetakan Kedua, PT. Bumi Aksara, Juni.

Firdaus, M. faza and Hosen, M. N. (2014). Efisiensi Bank Umum Syariah Menggunakan Pendekatan Two-Stage Data Envelopment Analysis. Buletin Ekonomi Moneter dan Perbankan, 16(2): 167-188. doi: 10.21098/bemp.v16i2.31.

Gambacorta, L. and Shin, H. S. (2018). Why bank capital matters for monetary policy. Journal of Financial Intermediation, 35(558),: 17-29. doi: 10.1016/j.ji.2016.09.005.

Kadang, J. (2018). Factors Influencing Profit Efficiency of Banking in Indonesia. Journal of Developing Economies, 3(2):. 1. doi: 10.20473/jde.v3i2.9211.

KSK 33 TAHUN 2019, B. I. (2019). KSK 33 TAHUN 2019 Bank Indonesia.. Available at: https://www.bi.go.id/id/publikasi/perbankan-danstabilitas/kajian/Pages/KSK 3319.aspx.

KSK 34 TAHUN 2019 Bank Indonesia (2020). KSK 34 Tahun 2019 Bank Indonesia.

Nisa, C. (2018). Evaluasi Efisiensi Perbankan Di Indonesia Berdasarkan Kategori Jumlah Modal Inti. JBMI (Jurnal Bisnis, Manajemen, dan Informatika), 15(2): 101. doi: 10.26487/jbmi.v15i2.4131.

Porcelli, F. (2009). Measurement of Technical Efficiency:: A brief survey on parametric and non-parametric techniques. Retrieved February, (January),1-27. Available at: http://citeseerx. ist.psu.edu/viewdoc/download?doi=10.1.1.232.4843\&rep=r ep1\&type=pdf.

Qurniawati, S. (2013). Efisiensi Perbankan Di Indonesia Dan Pengaruhnya Terhadap Return Saham Dengan Pendekatan Data Envelopment Analysis (DEA). BENEFIT Jurnal Manajemen dan Bisnis, 17(1): 27-40.

Sari, N. K. \& Widaninggar, N. (2018). Efisiensi Bank dalam Kelompok BUKU 4 di Indonesia: Pendekatan Data Envelopment Analysis. AFRE (Accounting and Financial Review), 1(2). doi: 10.26905/afr.v1i2.2409.

Sharma, S., Raina, D. and Singh, S. (2012). Measurement of technical efficiency and its sources: An experience of Indian banking sector. International Journal of Economics and Management, 6(1):. 35-57.

Nicholson, W. and Snyder, C.N. (2010) Intermediate Microeconomics and Its Application. $11 \mathrm{E}$. Cengage 
Tahir, I. M. and Haron, S. (2008). Technical efficiency of the Malaysian commercial banks: A stochastic frontier approach. Banks and Bank Systems, 3(4): 65-72.

Peraturan Bank Indonesia Tentang Kegiatan Usaha Dan Jaringan Kantor Berdasarkan Modal Inti Bank.', Pbi No 12, p. 58. Available at: http://www.bi.go.id/id/peraturan/moneter/Documents/pbi_151513.PDF. 